\title{
A importância da comunicação oral eficiente para o sucesso do profissional de secretariado executivo
}

\author{
The Importance of Effective Oral Communication to Success of Professional \\ Executive Secretariat
}

\author{
Jociléia Alves Gomes ${ }^{1}$ \\ (jocileia_gomes@hotmail.com) \\ Vanessa Alves da Silva ${ }^{1}$ \\ (vane.alvess@hotmail.com) \\ Elizete Teixeira da Silva ${ }^{l}$ \\ (elits28@hotmail.com) \\ Suianny Francini Conceição Luiz ${ }^{2}$ \\ (suiannyfrancini@yahoo.com.br) \\ Marlete Beatriz Maçaneiro ${ }^{3}$ \\ (marlete.beatriz@yahoo.com.br) \\ http://dx.doi.org/10.5216/cei.v15i2.24677
}

\begin{abstract}
Resumo
Este artigo discute a importância da oratória eficiente para o profissional de Secretariado Executivo e como ela contribui ao seu sucesso. O principal objetivo é buscar identificar a relevância e necessidade da comunicação oral de qualidade como requisito de crescimento profissional, analisando como a oratória poderá influenciar em sua imagem e a contribuição para o desenvolvimento da organização na qual está inserido. Foi utilizada a abordagem quantitativa, por meio da estratégia de levantamento (Survey). Os principais resultados obtidos dizem respeito à frequência de utilização da comunicação oral, exigindo desse profissional o domínio para tal atividade, devido a sua atuação estar mais ligada a área de atendimento e também a sua condição de agente facilitador, que estabelece relações com o todo da empresa, assessorando as mais diversas áreas e níveis hierárquicos, favorecendo assim sua imagem profissional.
\end{abstract}

Palavras-chave: Comunicação. Oratória. Secretariado Executivo.

\begin{abstract}
This paper discusses the importance of effective oratory to the Executive Secretary and how it contributes to their success. The main goal is to identify the relevance and need for quality oral communication as a requirement for professional goal, analising how Oratory influences their image and contribution for the advance of the organization in which they work. It uses a quantitative approach, by means of Survey strategies. The main results concern to the frequency of use of the Oral Communication, demanding mastery from these professionals due to them being more connected to customer service, and also to their condition as a facilitator that stablishes relations with the Company as a whole, aiding diverse areas and hierarchic levels, favouring their professional image.
\end{abstract}

Keywords: Communication. Oratory. Executive Secretariat.

\footnotetext{
${ }^{1}$ Graduadas em Secretariado Executivo pela Universidade Estadual do Centro-Oeste - Unicentro, Guarapuava - PR

${ }^{2}$ Especialista em Gestão Executiva e Assessoria Empresarial pela Unicentro (2010) e professora do Departamento de Secretariado Executivo da Unicentro. Brasil, Paraná, Curitiba.

${ }^{3}$ Mestre e doutora em Administração pela Universidade Federal do Paraná - UFPR e professora do Departamento de

Secretariado Executivo da Unicentro. Brasil, Paraná, Curitiba.
}

Comun. \& Inf., v. 15, n. 2, p. 14-33, jul./dez. 2012 


\section{Introdução}

A evolução histórica da profissão de Secretariado Executivo demonstra o desenvolvimento de suas atividades ao longo dos anos. Antes conhecido como profissional responsável apenas por atividades rotineiras, hoje tornou-se multifuncional e assessor gerencial. Tal profissional, atuante na área gerencial, participa de processos e necessita saber como alcançar os objetivos planejados.

Nesse contexto, a comunicação assume importante papel para o desenvolvimento tanto do profissional quanto das empresas no cenário atual. Torna-se um elemento fundamental no sucesso de uma organização, uma vez que, quando uma mensagem é transmitida de forma clara e eficiente, os resultados surgem com maior facilidade, trazendo benefícios ao público interno e externo.

Especificamente, a comunicação oral faz parte da rotina de trabalho dos profissionais de Secretariado Executivo, tendo de ser eficaz, clara e convincente. Esse profissional, enquanto assessor executivo, necessita aperfeiçoar o processo de comunicação melhorando o desempenho de suas atividades, pois "os estudos acadêmicos em Secretariado Executivo devem refletir conhecimentos que estejam associados às práticas, teorias e relações de Assessoria." (NONATO JÚNIOR, 2009, p. 157).

Conforme as mudanças do mercado, também o profissional deve ter a capacidade de se adaptar com facilidade a novos desafios, tendo condições de conhecer, interpretar e interagir em todos os processos organizacionais, principalmente no de comunicação. Dessa forma, este profissional atua como "gestor do conhecimento no ambiente de trabalho, congregando os mais diversos conceitos que envolvem o fazer e o saber do Secretário Executivo em suas atividades de cunho gerencial." (NONATO JÚNIOR, 2009, p. 158-159). Esse conhecimento advém do fluxo de informações gerenciado nas atividades de assessoria executiva.

Em razão disso, este artigo aborda a necessidade de uma comunicação oral eficiente para a prática do profissional de Secretariado Executivo, fazendo com que adquira confiança em suas funções, dialogando com os diversos setores da empresa em que atua. Dessa maneira, levantam-se as seguintes questões de pesquisa: quais as contribuições que a comunicação oral eficiente pode proporcionar ao profissional de Secretariado Executivo no exercício de suas atividades? Como a oratória poderá influenciar na sua imagem?

Para responder a esses questionamentos, o objetivo geral deste estudo é identificar a importância e necessidade da comunicação oral eficiente para o profissional de Secretariado Executivo, analisando como a oratória pode influenciar na sua imagem e como ela contribui para o

Comun. \& Inf., v. 15, n. 2, p. 14-33, jul./dez. 2012 
crescimento profissional e desenvolvimento da organização na qual está inserido. Como objetivos específicos, buscou-se identificar qual a frequência com que o profissional de Secretariado Executivo tem abertura para tomar decisões de forma independente no trabalho; verificar qual a importância da comunicação oral eficiente no trabalho em equipe; e observar qual a relevância da linguagem corporal e do ritmo da fala na transmissão de informações.

No decorrer dos próximos capítulos, far-se-á uma breve discussão do processo de comunicação organizacional, da teoria e tipos de comunicação e informações sobre a relação do profissional de Secretariado Executivo com essa área. Também será realizada a descrição dos procedimentos metodológicos usados para confeccionar este artigo e, no capítulo 4, serão feitas as análises dos dados coletados em campo e, por fim, as considerações finais.

\section{Referencial Teórico}

As contribuições de diversos pesquisadores como Rego (1986) e Tavares (2007), falando sobre comunicação, associados ao pensar de Medeiros e Hernandes (2009), explanando sobre a eficácia desta e juntamente com a ideia de outros autores que falam sobre este tema, estabeleceram o critério teórico para tal estudo.

De acordo com Restreppo (1995, apud BÍSCOLI; LOTTE, 2006, p. 162), “a comunicação pode ser entendida como um composto que dá forma à organização, que a informa fazendo-a ser o que é”. Considerando essa perspectiva, o autor estabelece quatro dimensões do processo de comunicação organizacional. A primeira diz respeito à divulgação, no sentido de tornar público determinado assunto; a segunda refere-se à informação, enquanto configurador das operações próprias de cada organização; a terceira, gerador de relações voltadas para a formação, a socialização e o reforço de processos culturais. E a última, como participação, ação de comunicação do "outro". Nesse ponto se completa o ciclo da comunicação, no qual explicitamente se dá a palavra ao outro, escutando-o e reconhecendo-o.

A comunicação é um atributo essencial da atividade humana, dela dependendo o entendimento social, familiar e profissional. O êxito da empresa, do executivo e do Secretário Executivo depende de suas habilidades individuais de comunicação (PINHEIRO, 2005). Sendo assim, ela se inclui em qualquer contexto organizacional, devendo ser obrigatoriamente organizada, para que haja um bom entendimento do que se quer transmitir.

Comun. \& Inf., v. 15, n. 2, p. 14-33, jul./dez. 2012 
Portanto, o profissional encontra-se envolvido neste momento devendo ter como principal qualidade a capacidade de relacionar-se bem com o executivo e demais membros. Exige-se dele a compreensão das relações humanas, em que deve aprender a ouvir tão bem quanto a falar. É neste âmbito que uma boa oratória é considerada de plena importância para o exercício das atividades deste conhecedor da área, uma vez que depende de uma comunicação compreensível.

Segundo Gómez (2006), a comunicação admite várias classificações. Quanto ao meio empregado pode ser verbal, não verbal e escrita. A comunicação verbal ou oral permite, através do uso da palavra, interação entre emissor e receptor, comunicando grande quantidade de mensagens em pouco tempo. SENAC (1996) confirma essa ideia, afirmando que a linguagem verbal permite o entendimento entre as pessoas, por meio dos signos falados. Porém tem como principal desvantagem a má interpretação das palavras e a existência de obstáculos na comunicação, impedindo que a mensagem seja transmitida de modo eficaz. (GÓMEZ, 2006). A comunicação não verbal é expressa por meio de manifestações corporais, são "sinais que produzimos, gestos que fazemos, imagens que criamos ou percebemos [...] Comunicações desse tipo auxiliam, muitas vezes, a fala" (SENAC, 1996, p. 28). E a escrita é transmitida por meio da linguagem escrita, compreendendo a comunicação impressa. "É a representação dos sons articulados na fala, em sinais gráficos, uma transformação da língua natural em outro código”. (SENAC, 1996, p. 45)

Para uma comunicação eficaz, o emissor deve procurar esclarecer suas ideias antes de comunicá-las. Para tanto, Medeiros (2010) afirma que para transmitir uma informação eficaz devese analisar com qual pessoa você vai comunicar-se, quem é ela, o que você quer transmitir, como está transmitindo as informações, se está usando as palavras adequadas às circunstâncias. São questionamentos que ajudam a analisar se a mensagem está sendo transmitida de forma compreensível.

Em muitos casos, a comunicação deixa de ser eficaz por vários fatores, um deles é a timidez, fator capaz de interromper a relação entre emissor-receptor. O prestígio, o status, a atração sexual, e outros, podem influenciar de forma positiva ou negativamente no que está sendo transmitido (MEDEIROS; HERNANDES, 2009). Para que a comunicação se torne eficaz deve-se atingir seus objetivos, de forma que haja reciprocidade em relação aos desejos e intenções de outro. Segundo Flois (2001), o medo de falar em público é um dos maiores empecilhos às pessoas que desejam realizar seus objetivos, pois quando se manifesta, geralmente inibe a pessoa. 
O medo, geralmente ocorre, devido a dois grandes fatores: falta de domínio do assunto e falta de planejamento da apresentação. Por isso faz-se necessário que, além de definir o assunto, a pessoa que fará a apresentação também o domine, já que é muito fácil sentir medo de falar se não tem segurança do que vai falar. A maior parte das pessoas que tentam romper essa barreira, somente começarão a perder o medo se a sua primeira experiência com o público for boa. Mas, para isso, ela precisa ser bem planejada. (FLOIS, 2001, p.10)

Por isso, para que o medo não venha a atrapalhar a boa oratória, faz-se necessário conhecer o conteúdo e o público, tornando mais fácil a exposição do assunto. Silva (2007, p. 1) conceitua oratória como "a arte de falar em público. Mas além de falar com desenvoltura é necessário comunicar. Mais importante que a boa oratória é a comunicação eficaz".

Considerando que no mundo dos negócios, as organizações procuram profissionais cada vez mais completos e competentes para se comunicar, a comunicação entra como uma habilidade que pode ser desenvolvida. A comunicação intrapessoal e a autoestima são essenciais nesse processo, pois se a pessoa acreditar que pode mudar estará apta a se tornar um boa comunicadora e abrir a possibilidade efetiva de comunicação com o outro. (MARTINS; FORTES, 2008).

Assim, o Secretário Executivo deve saber administrar o medo de falar em público, para que este se torne seu aliado, e não um obstáculo. O medo pode ser um elemento positivo e desafiador quando se quer ser mais eficiente, devido ao aumento da preparação para exposição de um assunto. Polito (1999) afirma que uma das atitudes para se vencer o medo de falar em público é acreditar na sua capacidade, é descobrir os aspectos positivos da Expressão Verbal - com isso adquire confiança em si mesmo.

Uma das principais qualidades desejáveis do Secretário Executivo é a capacidade de se comunicar bem com as pessoas com quem trabalha, sendo que, além de dominar os mais variados conhecimentos técnicos, econômicos e financeiros, precisa também ter um bom comportamento interpessoal. Pode-se considerar que, sem um diálogo eficaz, não há entendimento da mensagem, o que ocasiona dificuldades de relacionamento interno e externo, baixando a produtividade. As organizações são entidades vivas, constituídas de pessoas e precisam manter o equilíbrio na comunicação para sua sobrevivência. (MARTINS; FORTES, 2008).

De acordo com Oliveira (2011), esse agente facilitador que é o profissional de Secretariado Executivo possui o marco de sua existência que é a condição de assessoria, a qual se articula com diferentes áreas, podendo atuar com atendimento ao público e ao telefone, em reuniões, vendas, eventos e outras. Por isso, a importância do domínio da comunicação. Além disso, o profissional de 
Secretariado Executivo, ao se comunicar, faz uso dos três tipos de comunicação: verbal, não verbal e escrita. Ele redige e elabora documentos, utilizando a palavra escrita, mas precisa da palavra falada para dar sua opinião e partilhar seus conhecimentos. Assim, a comunicação verbal é usada com predominância, uma vez que esta pessoa está mais ligada às relações humanas, tendo de se comunicar de forma compreensível, transmitindo credibilidade, pois do contrário, demonstrará incapacidade comunicacional.

O profissional dessa área deve ter habilidade para saber se comunicar com diferentes níveis hierárquicos da organização, adaptando seu discurso para que a mensagem seja compreendida por todos. Segundo Polito (1999, p. 85), “sem público não existe orador, pois é ele quem indicará os rumos a serem tomados por aquele que fala”. Assim, faz-se necessário conhecer, antecipadamente, o público ao qual irá se comunicar, buscando saber o que ele espera da empresa, o conhecimento que tem sobre tal assunto ou momento, para que a comunicação atinja seu objetivo.

Compreende-se que reconhecer e valorizar o cliente como fator primordial para a qualidade da empresa ajuda a mantê-la no mercado competitivo. Além de elevar o seu status junto ao público externo, torna-se uma eficiente tática para o sucesso organizacional. Isso demonstra que cada vez mais se exige dos profissionais essa habilidade, inclusive do (a) Secretário (a) Executivo (a), porque muitas vezes atua nessa área de atendimento.

Outro fator que garante sucesso a organização é o bom atendimento ao telefone. Pelo fato da área de Secretariado Executivo estar inserida nesse processo, precisa garantir um eficiente contato telefônico. Por meio da dicção, do timbre de voz e da linguagem se garante uma comunicação adequada. Dar atenção, ter polidez no tratamento e habilidade na conversação, tornando mais fácil a comunicação e o convívio (MATOS, 2004). Nesse tipo de atendimento, o colaborador deve apresentar expressões gentis, dialogar de forma breve, as frases devem ser flexíveis e repassar simpatia, pois é responsável por fornecer ao cliente informações claras e objetivas.

A pessoa que trabalha na área de Secretariado Executivo também atua auxiliando em reuniões, tornando-a mais eficiente. Na visão de Matos (2004), há algumas dicas que podem ser adotadas por esses profissionais para auxiliar e evitar perda de tempo em uma reunião. Precisa saber o número de participantes e ter conhecimento da pauta, que deve ser disponibilizada com antecedência aos participantes. A partir disso, deve preparar o local da reunião, disponibilizando todo material a ser utilizado. Não marcar mais do que três reuniões diárias e evitando que sejam realizadas no final do dia. Por atuar como assessor, também pode vir a conduzir reuniões, fazendo

Comun. \& Inf., v. 15, n. 2, p. 14-33, jul./dez. 2012 
uso das técnicas de oratória: introdução, preparação, uso de apoios para melhor argumentação, recapitulação e conclusão. São elementos indispensáveis para que esse momento se torne claro, objetivo e bem estruturado.

Além disso, ele pode auxiliar na organização de eventos, atuando nas funções ligadas à coordenação, supervisão e controle das atividades do evento, além de desempenhar alguma apresentação, que exija dele domínio das técnicas eficientes de oralidade. Sabino e Rocha argumentam que:

A secretária tem um grande desdobramento das suas atividades. Ela pode contribuir na organização e métodos da empresa, pode organizar eventos, pode fazer levantamentos e relatórios, é capacitada para intermediar relações e mediar conflitos, além da gama de atividades técnicas de redação, tradução, informática, arquivos, etc. (SABINO e ROCHA, 2004, p. 94).

Assim, busca-se do profissional de Secretariado Executivo a capacidade técnica para atuar nas mais variadas áreas, assessorando e auxiliando na execução das funções características a cada setor. Sendo assim, percebe-se que a comunicação oral eficiente é elemento importantíssimo para o sucesso pessoal e profissional do indivíduo que ocupa essa área de Secretariado Executivo, promovendo uma relação satisfatória de diálogo entre ambiente interno e externo de uma organização.

\section{Metodologia}

Neste estudo foi utilizada a abordagem quantitativa, que segundo Richardson (1999, p.74), “caracteriza-se pelo emprego da quantificação tanto nas modalidades de coleta de informações, quanto no tratamento delas por meio de técnicas estatísticas." Esse método de pesquisa é um processo de coleta de dados que prioriza números e informações que possam ser qualificadas.

Nesse sentido, foi utilizada a estratégia de pesquisa de levantamento (Survey), que tem como objetivo técnico a utilização de questionário. A coleta de dados foi realizada com uma amostra aleatória de 90 profissionais atuantes e formados na área de Secretariado Executivo de empresas da cidade de Guarapuava, Londrina e Francisco Beltrão. Foram respondidos 31 questionários que estarão contemplados nesta análise. O período de aplicação do questionário foi de 08 de julho a 22 de agosto de 2012. Salienta-se que foi feito o pré-teste com 10 acadêmicas do $4^{\circ}$ ano do curso de Secretariado Executivo da Universidade Estadual do Centro-Oeste - UNICENTRO.

Após a coleta dos dados, buscou-se interpretar os fenômenos de acordo com o contexto estudado, sendo feita uma triangulação dos resultados obtidos. Para Minayo, Assis e Souza (2005),

Comun. \& Inf., v. 15, n. 2, p. 14-33, jul./dez. 2012 
a triangulação foi inicialmente definido como a combinação e o cruzamento de múltiplos pontos de vista, sendo uma tarefa conjunta de pesquisadores com formação diferenciada. A visão de vários informantes e o emprego de uma variedade de técnicas de coleta de dados que acompanham o trabalho da investigação e do seu uso, possibilitando na prática a interação, crítica intersubjetiva e comparação. No caso deste estudo, a triangulação foi utilizada na análise dos dados coletados empiricamente, com o levantamento efetuado da literatura.

\section{Discussão e Análise de Dados}

Os dados foram coletados a partir da resposta de 31 questionários enviados, via e-mail pelo Google Docs, a profissionais de Secretariado Executivo. O primeiro questionamento buscou avaliar se o tempo de trabalho foi suficiente para identificar ou formar o conceito dos profissionais de que a oratória eficiente é elemento essencial para sua função. Dos 31 respondentes, 52\% atuam na área entre 1 a 3 anos e 32\% há mais de cinco anos. Esse período já pode ser considerado como base para um conceito sobre o tema abordado, pela frequência do uso da comunicação.

Em relação ao perfil dos entrevistados, verificou-se que há predominância do sexo feminino, representando $87 \%$ e $13 \%$ são do sexo masculino. Sendo uma parcela pouco significativa, quando se leva em conta que nos últimos anos, houve uma tendência de crescimento de profissionais do sexo masculino nesta área de atuação. Observou-se também que 17 profissionais têm entre 26 e 35 anos de idade (55\% dos respondentes), seguidos de 10 entre 21 e 25 anos (32\%). Isso indica que cada vez mais jovens buscam por essa área, considerando que esta profissão é uma das mais novas no mercado de trabalho.

Procurou-se verificar com os pesquisados em qual área do Secretariado Executivo que mais atuam. De acordo com o Gráfico 1, observa-se que a área de atendimento telefônico e ao público teve um número maior de frequências, do que em relação a outras áreas das assessorias. Isso demonstra que, atualmente, a maioria desses profissionais não exerce exatamente as funções que lhe competem, geralmente desempenham diversas atividades, dentre elas o setor de atendimento. São poucos os profissionais que atuam com assessorias, são aqueles que trabalham em empresas maiores, que lhes possibilitem exercer tal função. Pelo fato de atuarem mais na área de atendimento, é de suma importância que tenham uma boa oratória. Conforme já mencionado por Oliveira (2011), esse trabalhador assume papel importante como fornecedor de informações da empresa, se articula com diferentes setores, faz encaminhamentos, deve reconhecer e valorizar os clientes como pessoas

Comun. \& Inf., v. 15, n. 2, p. 14-33, jul./dez. 2012 
principais para a empresa e ter habilidades para saber lidar com essa área. Também lhe cabe atender bem ao telefone, garantindo que a mensagem seja compreendida e transmitida de maneira adequada.

Gráfico 1 - Áreas de Atuação do Profissional de Secretariado Executivo

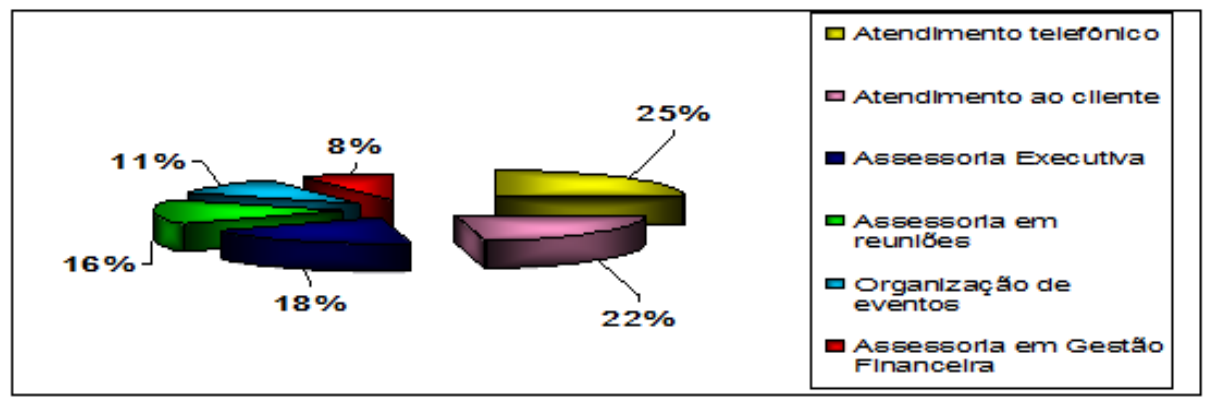

Fonte: Dados da pesquisa (2012).

Uma boa comunicação oral é importante para o profissional de Secretariado Executivo? Pode ser um dos requisitos para se conquistar o sucesso profissional? Esses questionamentos relacionam-se a pergunta seguinte, em que visa verificar se os pesquisados consideram este item importante para a profissão. A pergunta era aberta, o que possibilitou a coleta de várias opiniões. Em geral, todos consideraram o domínio da comunicação oral item muito importante para o sucesso dessa ocupação. A partir das respostas, verificou-se que uma boa comunicação oral é requisito obrigatório, tendo em vista que o profissional está sempre interagindo, sendo ainda elemento indispensável, pois precisa repassar as informações de forma clara, objetiva e eficiente. A oralidade também permite que ele demonstre confiança que conhece o assunto, transmitindo com clareza as informações. Pelo fato desse profissional precisar falar diariamente com todas as categorias de contatos da organização, exige-se dele que, além de uma comunicação oral eficiente, seja polivalente e dinâmico.

Também foi verificado com que frequência esses profissionais têm abertura para tomar decisões de forma independente no trabalho. Do total de pesquisados, $44 \%$ às vezes têm abertura para tomar decisões; no entanto, $41 \%$ afirmaram ter sempre abertura para isso. Estes números revelam que esse profissional tem adquirido seu espaço nas empresas, demonstrando confiança e capacidade para lidar com os desafios. Conforme sustentam Lasta e Silva (2007), a área secretarial vem demonstrando um novo perfil, o secretário gestor, que passa a trabalhar para a empresa, não apenas para o executivo. "É capaz de tomar decisões, de exercer a liderança com clientes internos e

Comun. \& Inf., v. 15, n. 2, p. 14-33, jul./dez. 2012 
externos, de planejar as ações a serem realizadas, de controlar e organizar seu ambiente de trabalho" (LASTA; SILVA, 2007, p.1). Deixou de ser simples executor de tarefas para exercer funções criativas, com capacidade de opinar e decidir, pois é um ser inteligente e com capacidades individuais significativas para a organização. Nesse aspecto a comunicação se torna primordial.

Visando avaliar como o profissional de Secretariado Executivo sente-se ao comunicar-se com membros internos e externos à organização, foi elaborada a próxima questão, em que se obtiveram os seguintes resultados de acordo com o Gráfico 2. Verificou-se que a maioria (55\%) se sente preparada para se comunicar com todos, sejam eles superiores ou subordinados. Isso revela que esses profissionais tiveram uma boa formação sobre comunicação. Além disso, $24 \%$ dos pesquisados sente-se tranquilos e seguros ao ser comunicar, demonstrando o domínio do assunto e boa capacidade de repassar as informações. A mesma porcentagem se observa daqueles que pensam positivo, quando têm domínio do assunto, evitando erros ao se comunicar. Apenas 12\% dos pesquisados afirmaram se sentir inseguros, ter medo de errar ao comunicar-se, o que se resolve com treinamentos e conhecimento/domínio do assunto.

Gráfico 2 - Comunicação na Relação Interpessoal

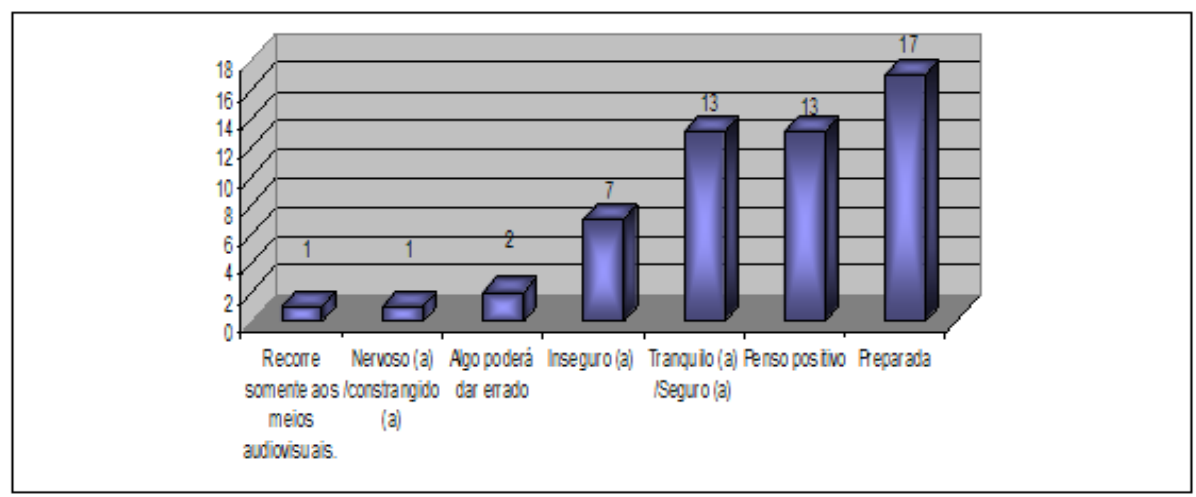

Fonte: Dados da pesquisa (2012).

A questão seguinte colocou o pesquisado diante de uma situação do dia a dia, questionando como ele reagiria se, ao atender ao telefone, a pessoa que estivesse ouvindo não entendesse a ideia que se pretendia transmitir. Os resultados são apresentados no Quadro 1. Verifica-se que, na primeira situação, a maioria (37\%) se preocuparia em reformular a informação de uma maneira que a pessoa compreendesse. No entanto, $23 \%$ dos pesquisados iriam sugerir à pessoa para que viesse até a empresa. Outra opção considerada mais relevante, representando $21 \%$ das respostas, é que poderiam sugerir outro meio de comunicação para repassar a informação e $19 \%$ iriam apenas repetir

Comun. \& Inf., v. 15, n. 2, p. 14-33, jul./dez. 2012 
a informação sem reformulá-la. São situações que o profissional de Secretariado Executivo que atua nesta área de atendimento pode vir a enfrentar, cabendo a ele saber lidar com isso, transmitindo a ideia de forma clara e eficiente. É o que esclarece Matos (2004), devido a estar inserido nessa área, precisa garantir um eficiente contato telefônico. É necessário ser educado, ter polidez no tratamento e habilidade na conversação tornando mais fácil a comunicação e o convívio.

\section{Quadro 1 - grau de importância de certas situações}

\begin{tabular}{|c|c|c|c|c|c|}
\hline & 5 & 4 & 3 & 2 & 1 \\
\hline Preocupa-se em reformular a informação de outra maneira, de forma mais compreensível. & 21 & 6 & & 2 & 2 \\
\hline Repete a informação exatamente como da primeira vez. & 11 & 10 & & 7 & 3 \\
\hline Sugere outro canal de comunicação para repassar tal informação. & 12 & 10 & & 6 & 3 \\
\hline Se a pessoa estiver próxima, sugere uma visita até a empresa para esclarecimentos. & 13 & 8 & & 6 & 4 \\
\hline TOTAL & 57 & 34 & & 21 & 12 \\
\hline
\end{tabular}

5 = mais relevante $\quad 4=$ relevante $\quad 3=$ indiferente $\quad 2=$ irrelevante $\quad 1=$ menos relevante

Fonte: Dados da pesquisa (2012).

A próxima questão apresenta outra situação para o pesquisado: o que ele faria se, ao tentar convencer a pessoa com a qual está conversando sobre uma decisão a ser tomada, ele percebe sua indiferença. Dos respondentes, $44 \%$ mencionaram que insiste com mais persuasão em seus argumentos para tentar convencer essa pessoa. Já $41 \%$ desistiram e esperariam por uma ocasião mais adequada. E os demais perguntariam o porquê tem dúvida sobre a decisão em questão. Isso revela que a maioria tem poder de persuasão, que não desiste de convencer ou comunicar no primeiro obstáculo que aparece. É o que afirma Medeiros e Hernandes (2009), de que é necessário merecer o respeito do receptor e inspirar confiança, apresentando fatos e argumentos relevantes, refletindo antes de falar e criando um clima de boa vontade e de expectativa positiva.

$\mathrm{O}$ questionamento posterior buscou identificar se esses profissionais, quando requisitados para apresentar algum produto ou serviço a seus colegas, gestores e clientes em potencial usam da criatividade para expor o assunto, conforme dados do Gráfico 3.

Gráfico 3 - Uso de Recursos para Apresentações de Produtos e Serviços

Comun. \& Inf., v. 15, n. 2, p. 14-33, jul./dez. 2012 


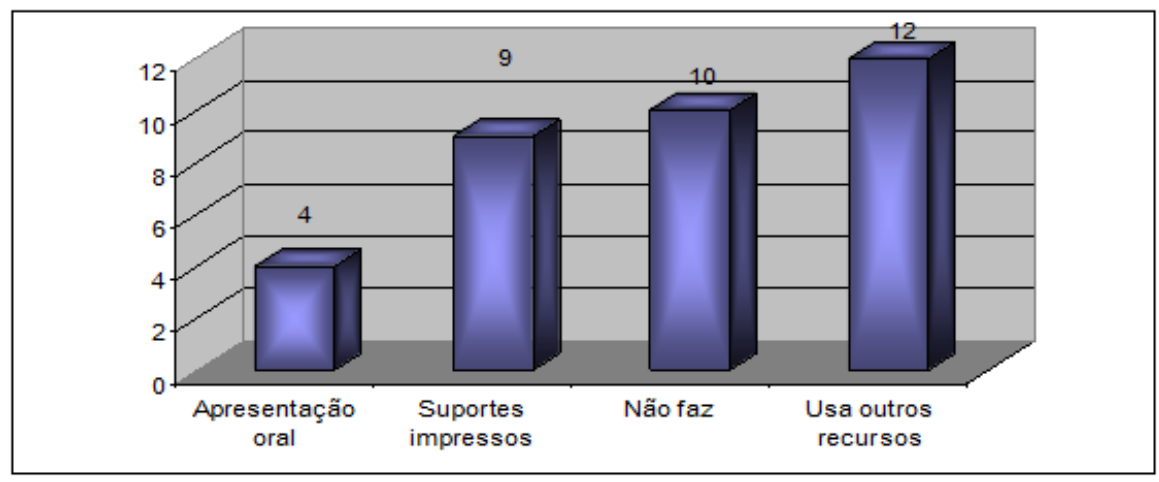

Fonte: Dados da pesquisa (2012).

Os dados mostram que, dos profissionais que realizam esse tipo de apresentação, $34 \%$ fazem uso de outros recursos, além da apresentação oral, o que fornece maior coerência ao que está sendo exposto, facilitando a compreensão. Entretanto $29 \%$, não fazem esse tipo de apresentação, ficando a cargo dos gestores ou outro profissional da empresa.

A próxima questão buscou a opinião dos pesquisados se a oratória pode influenciar na imagem profissional do (a) Secretário (a) Executivo (a) em vários aspectos, conforme apresentado no Gráfico 4. A maioria (52\%) afirmou que a oratória pode influenciar para dirigir ou participar de reuniões, pois se o profissional tiver uma boa capacidade comunicativa poderá expor sua opinião em reuniões, desde que fundamentada, além da possibilidade de dirigir uma reunião. Segundo Polito (1999), os empresários, executivos, técnicos, profissionais liberais necessitam cada vez mais da boa comunicação. Todos precisam falar bem para enfrentar as mais diferentes situações: comandar subordinados, dirigir ou participar de reuniões, apresentar relatórios, presidir solenidades, vender ou apresentar produtos e serviços, entre outros.

Gráfico 4 - Influência da Oratória na Imagem Profissional

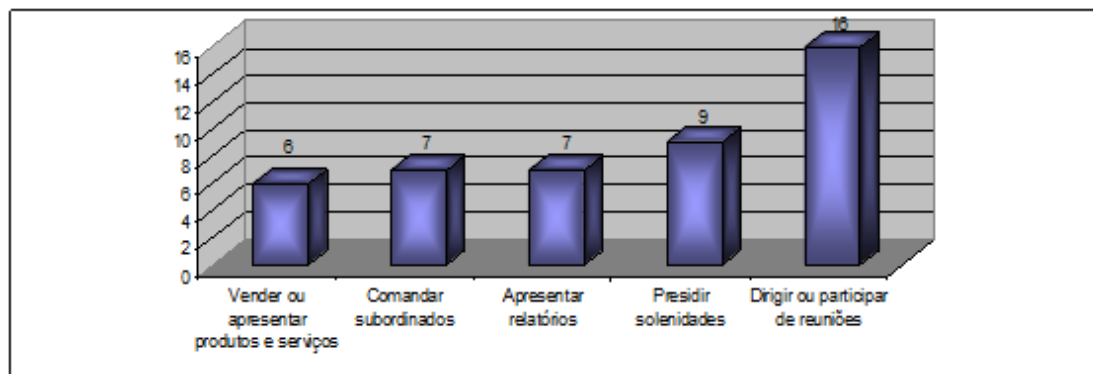

Fonte: Dados da pesquisa (2012).

Outra parte dos pesquisados, sendo $29 \%$, afirmaram que a oratória pode ajudar a presidir solenidades, haja vista que, se o profissional não tiver domínio do assunto e comunicação eficaz,

Comun. \& Inf., v. 15, n. 2, p. 14-33, jul./dez. 2012 
será impossível atuar nessa área. Os outros $23 \%$, disseram que a oratória pode ajudar a comandar subordinados e a apresentar relatórios. Percebe-se que o domínio da oratória eficaz é importante em momentos de exposição para pessoas superiores, que exige um nível mais alto de conhecimento e sabedoria. Conforme Polito (1999), um público culto é mais crítico, possui vocabulário extenso, é mais frio e disciplinado e não se deixa iludir por artimanhas verbais. No entanto, esse tipo de público pode ser encontrado junto a auditórios heterogêneos, devendo o orador preparar seu discurso não somente para atingir esse público, mas que todos possam entender a mensagem.

Com a próxima questão, buscou-se a opinião dos pesquisados se a comunicação oral é importante para ajudar no processo de trabalho em equipe. Todos os pesquisados afirmaram que é importante, pois uma equipe precisa compreender as diferentes ideias, intenções e atividades a serem desenvolvidas. Assim, efetivam-se as relações interpessoais, pois é a boa comunicação que promoverá um bom relacionamento, para a busca de soluções a possíveis problemas. Eles entendem que para uma equipe trabalhar em prol de um objetivo é necessário engajamento, o que só é possível através do convencimento de que o objetivo é um bem comum a todos os membros, tornando a equipe eficiente. Também consideram que a oratória, quando bem elaborada e em termos adequados, facilita o processo de comunicação, proporcionando segurança e confiança aos demais, permitindo que as informações tenham maior clareza e precisão.

Os respondentes ainda afirmam que saber ouvir, convencer e persuadir através de argumentos corretos, no momento ideal, são habilidades de uma boa liderança, as quais precisam ser valorizadas, pois a falha destas pode acarretar em sérios prejuízos à empresa. Confirmando essa ideia, Lasta e Silva (2007, p. 4) afirmam que a "liderança é uma das maiores virtudes de quem atua na área empresarial, pois o líder deve saber dizer sim, mas é necessário saber dizer não, pois não se admitem falhas atribuídas a este profissional”.

Em relação ao questionamento seguinte, buscou-se saber dos pesquisados se, em sua carreira profissional, já passaram por situações em que a falta das técnicas de comunicação oral comprometeu o resultado do objetivo proposto. Considerando as respostas coletadas, a maioria (52\%) afirmou que não passou por esse tipo de situação, o que demonstra que esses profissionais têm domínio das técnicas de comunicação oral. No entanto, parcela significativa (48\%) dos pesquisados responderam já ter passado por essa situação, havendo diversos relatos deste ocorrido.

Além disso, grande parte dos entrevistados afirma que um dos problemas que afetou o bom desempenho na apresentação foi a insegurança ao transmitir a informação, problema este, causado

Comun. \& Inf., v. 15, n. 2, p. 14-33, jul./dez. 2012 
em geral pela falta de informações sobre o assunto, dificultando a exposição clara. Então, caso seja convidado para fazer esse tipo de apresentação, cabe buscar informações sobre o assunto e conhecer as técnicas referentes à comunicação oral. Polito (1999) afirma que as pessoas devem buscar conhecer os aspectos positivos de sua comunicação, tentando aperfeiçoá-los, para que reforce o conjunto da Expressão Verbal. Esse processo de adquirir confiança e segurança da fala é lento, pode demorar anos até que ocorra uma completa transformação.

O próximo questionamento buscou identificar qual o grau de dificuldade encontrado ao desenvolver atividades na área de comunicação oral, conforme dados do Gráfico 5. Dos profissionais entrevistados, $42 \%$ encontram dificuldades com recursos financeiros, muitas vezes por a empresa não possuir um orçamento pré-definido para formação de seu quadro profissional. Outro fator significativo encontra-se no relacionamento com os demais setores da empresa (19\%), seguido do relacionamento com os gestores (16\%). A infraestrutura adequada também é um fator relevante, na margem dos $13 \%$ das opiniões, pois nem sempre a empresa tem a perspicácia ou o entendimento necessário de que é preciso um ambiente com sonorização apropriada e livre de ruídos, para uma boa compreensão da comunicação. Outros $10 \%$ mencionam o acesso à novas tecnologias, pois continuamente deparam-se com mudanças e inovações nessa área, o que geralmente tende a facilitar essas atividades.

Gráfico 5 - Situações de Comprometimento na Carreira Profissional

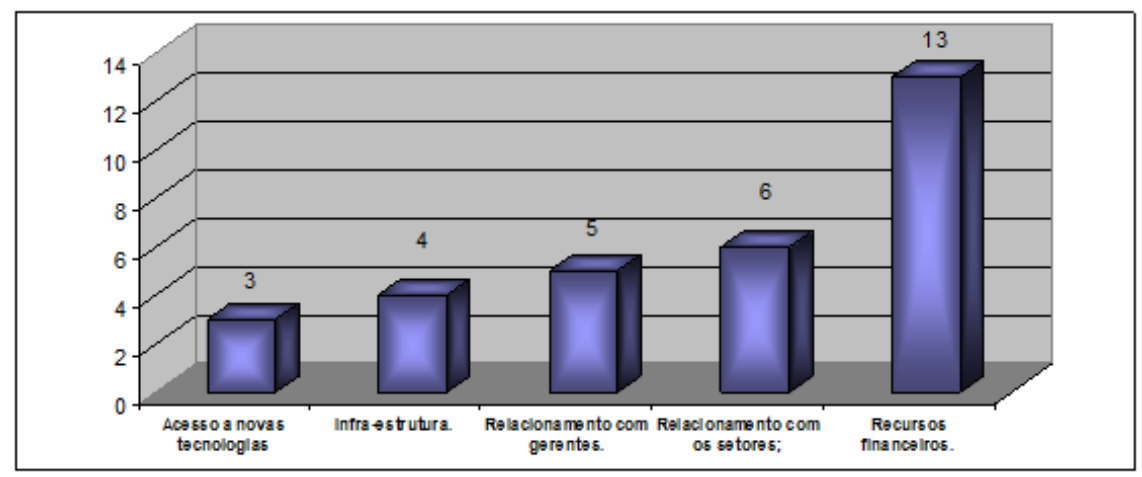

Fonte: Dados da pesquisa (2012).

A próxima indagação tratou da linguagem corporal, sendo que grande parte (81\%) utiliza-se deste recurso de forma correta para reafirmar o que se procura transmitir, dando mais ênfase a sua fala. Sabe-se que a comunicação não-verbal complementa a fala, como afirma Polito (1999, p. 71), “todo o nosso corpo fala quando nós estamos comunicando." Assim, a linguagem corporal serve de apoio às palavras, podendo valorizar o discurso, desde que empregada no momento certo.

Comun. \& Inf., v. 15, n. 2, p. 14-33, jul./dez. 2012 
Em relação à fala, é necessário manter um ritmo coerente com o tempo, o público e o local onde se pretende expor uma ideia, para facilitar a compreensão. Além disso, o domínio da alternância de ritmo faz com que haja um diferencial no momento de transmitir tal informação. $\mathrm{O}$ Gráfico 6 apresenta as respostas quanto a esta questão. Observou-se que parte dos profissionais pesquisados, sendo $42 \%$, conseguem administrar essa habilidade de alternância da fala, embora $32 \%$ assumem falar com rapidez, podendo a informação não ter sido transmitida de forma satisfatória. De acordo com Polito (1999), o ritmo é a musicalidade da fala, é preciso aperfeiçoá-lo dentro do estilo de cada um, aproveitando o timbre e a sonoridade da voz. O ritmo e a cadência da fala podem ser conquistados com simples exercícios de leitura de poesia, em voz alta. Por isso, é tão importante o adequado ritmo da fala, pois é uma caraterística relevante que pode prender a atenção do ouvinte ou leva-lo à rejeição.

Gráfico 6 - Avaliação do Ritmo de Fala

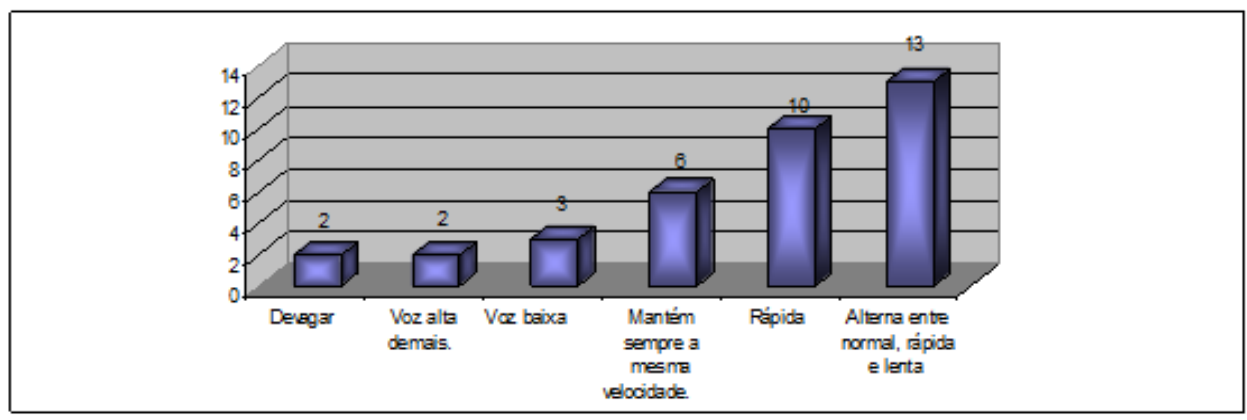

Fonte: Dados da pesquisa (2012).

Devido os profissionais de Secretariado Executivo se depararem frequentemente com a área de atendimento, perguntou-se que fatores da comunicação consideram importantes para um bom atendimento ao cliente, conforme dados do Gráfico 7. A maioria dos pesquisados (42\%) afirmaram que saber ouvir é um dos fatores que mais contribuem para se atender o público com eficácia. Seguido pela comunicação clara, que representa $23 \%$ dos pesquisados, pois se não souber se comunicar com clareza, certamente a mensagem não será compreendida pelo receptor. Ao estar diante de uma pessoa, é preciso demonstrar confiança e segurança a respeito das informações que serão fornecidas, devendo ser repassadas com clareza, pois a falta desta pode acarretar incompreensões ou mesmo criar problemas sérios de comunicação. "Atender de forma precisa, ágil e cordial demonstra ao cliente o quanto ele é importante para a sua empresa." (BARATS; BORGES, 1998, p. 43).

Gráfico 7 - Fatores Importantes da Comunicação para o Bom Atendimento ao Cliente

Comun. \& Inf., v. 15, n. 2, p. 14-33, jul./dez. 2012 


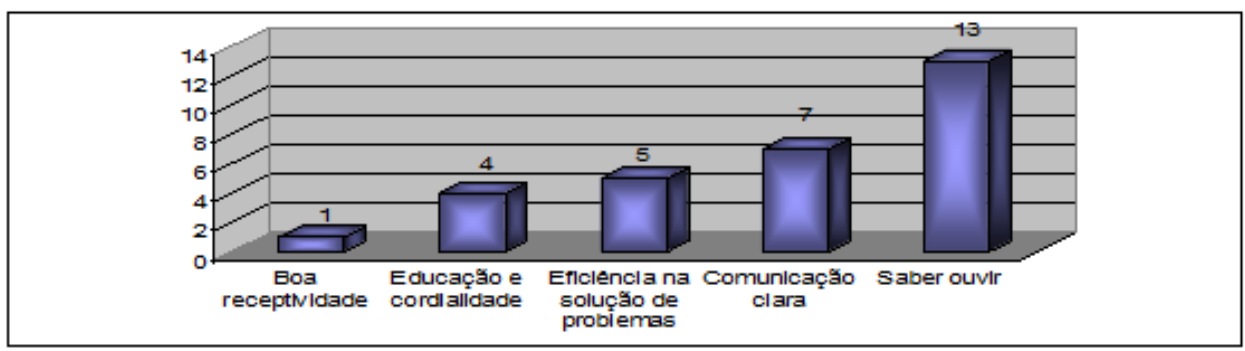

Fonte: Dados da pesquisa (2012).

Por fim, cabe salientar que, na atualidade, as organizações procuram focar no cliente, fazendo do bom atendimento um fator de sucesso e competitividade (PORTELA, 2006). Isso demonstra que, cada vez mais, exige-se dos profissionais essa habilidade, inclusive do (a) Secretário (a) Executivo (a), por muitas vezes atuar nessa área de atendimento.

\section{Considerações Finais}

Neste trabalho buscou-se mostrar algumas características básicas de uma boa oratória, para que se tenha sucesso no momento da comunicação. Sabe-se que, desde os tempos remotos, a oratória já fazia parte da comunicação dos povos. Atualmente deixa de ser privilégio de poucos e passa a ser um processo fundamental nas relações humanas e no progresso social, sendo um atributo essencial da atividade humana. Dela depende o entendimento social, familiar e profissional.

Não é diferente para o profissional de Secretariado Executivo, pois uma de suas qualidades desejáveis deve ser a capacidade de se comunicar bem, pois a comunicação é elemento essencial dentro e fora das organizações. Ela favorecerá o sucesso, desde que transmita informações eficazes, proporcionando maior segurança e eficiência no trabalho. O mercado busca pessoas com esse perfil, que além de possuírem bons conhecimentos técnicos também tenham uma boa comunicação com os clientes em potencial. Se o profissional de Secretariado Executivo não tem muito domínio da fala, pode vir a desenvolver essa habilidade, desde que acredite que pode mudar e tenha força de vontade. Para isto, deve primeiramente saber administrar o medo de falar em público, tornando-o seu aliado.

Observou-se também que, devido ao profissional de Secretariado Executivo estar mais ligado à área de atendimento, exige-se dele o domínio da comunicação oral eficiente, para que as informações sejam repassadas de forma compreensível e eficaz, evitando problemas à empresa. Assim, devido a sua condição de assessoria, ter uma boa comunicação é elemento primordial, que favorecerá a sua imagem profissional, e também o sucesso empresarial.

Comun. \& Inf., v. 15, n. 2, p. 14-33, jul./dez. 2012 
Acredita-se que este estudo trará contribuições importantes à teoria do Secretariado Executivo, pois há poucos livros que tratam sobre este assunto, especificamente, e que fornecem sugestões ou proposições de melhorias para esse problema. A partir do levantamento e análise dos dados, é possível tirar conclusões que podem ser seguidas por esses profissionais, a fim de ajudá-los no desenvolvimento de suas tarefas, buscando uma comunicação eficaz.

Além disso, este trabalho pode contribuir para a formação acadêmica, não só da área de Secretariado Executivo, mas também de outras áreas que utilizam a comunicação para estabelecer relações com outras pessoas, principalmente em organizações. E, também, por ser um assunto que sempre estará em discussão, pois a comunicação faz parte de toda organização; se há problemas com a troca de mensagens, por consequência, acarretará conflitos em geral.

Este estudo também trouxe lições de superação, concernentes ao medo de falar em público, fazendo deste um aliado para melhor preparação ao expor um assunto. Compreende-se hoje de maneira clara, que quando não se tem um bom domínio da fala, pode-se vir a desenvolver tal habilidade, mas desde que se tenha força de vontade e que acredite na mudança.

Salienta-se que o estudo realizado apresentou limitações quanto a escassez de material bibliográfico específico do Secretariado Executivo e da oratória, havendo a necessidade de se fazer uma ligação com áreas afins, como por exemplo, a da Comunicação Social.

É válido ressaltar ainda, em relação a aplicação do questionário, que alguns dos profissionais do Secretariado Executivo encontravam-se em férias ou em outras atividades externas à organização, dificultando o acesso a eles via telefone ou e-mail. Houve aqueles que se esqueceram de responder e retornar esses questionários, havendo a necessidade de um novo contato. Além disso, o medo de serem comprometidos com os resultados da pesquisa exigiu melhor preparo nos argumentos, assim como novas formas de contato e maiores explicações quanto ao sigilo de uma pesquisa científica, com o objetivo de repassar segurança e adquirir a confiança desses pesquisados.

Outra limitação foi o tempo de atuação na área, assim como a formação acadêmica também apresentaram suas limitações, pois muitas empresas possuem profissionais que trabalham a menos de três anos, o que se torna um agravante quando esses também não são diplomados em Secretariado Executivo ou possuem apenas o Ensino Médio.

Artigo submetido em 10/12/2012 e aceito em 21/03/2013.

\section{Referências}

Comun. \& Inf., v. 15, n. 2, p. 14-33, jul./dez. 2012 
ALCURE, Lenira; FERRAZ, Maria N. S; CARNEIRO, Rosane. Comunicacão verbal e naoverbal. Rio de Janeiro : SENAC/DN/DFP, 1996. 80 p. Il. Inclui bibliografia.

BARATS, C. M.; BORGES, M. M. Técnicas de recepção. Rio de Janeiro: SENAC DN, 1998.

BISCOLI, F. R. V.; LOTTE, R. I. Reflexões teóricas sobre a importância da comunicação em Secretariado Executivo. Revista Expectativa, Toledo-PR, v. 5, n. 5, 2006.

BRASIL. Lei ${ }^{\circ}$ 7.377, de 30 de setembro de 1985. Diário Oficial da República Federativa do Brasil, Brasília, DF, 1 out. 1985. Disponível em: <http://www.fenassec.com.br/bosecretariado_ leiregulamentacao.html>. Acesso em: 14 nov. 2012.

FLOIS, L. A. C. A importância da comunicação para secretários executivos. Revista Expectativa, Toledo, v.1, n. 1, p. 9-12, 2001. Disponível em: <http://e-revista.unioeste.br/index.php/expectativa/ article/ view/499/413> Acesso em: 05 maio 2012.

GIL, A. C. Métodos e técnicas de pesquisa social. 6. ed. São Paulo: Atlas, 2009.

GÓMEZ, M. R. Manual práctico de secretarido. España: Ra-Ma, 2006.

LASTA, A.; SILVA, A. O Secretariado Executivo e a função de gestão. Secretariado Executivo em Revista. v. 3, 2007. Disponível em: <http://www.upf.br/seer/index.php/ser/article/view/1761/ 1170>. Acesso em: 21 out. 2012.

MARTINS, C. M. T.; FORTES, G. W. A expressividade da comunicação oral e sua influência no meio corporativo. Revista Communicare, São Paulo, n. 2, v. 8, 2008. Disponível em:

<http://www.facasper.com.br/upload/publicacoes/7/Communicare\%208.2.pdf> Acesso em: 12 jun. 2012.

MATOS, M. Secretária(o): tudo começa assim... Fortaleza: Premius, 2004.

MEDEIROS, J. B.; HERNANDES, S. Manual da secretária. 11 ed. São Paulo: Atlas, 2009.

MEDEIROS, J. B. Redação empresarial. 7. ed. São Paulo: Atlas, 2010.

MINAYO, M.C. de S.; ASSIS, S. G.; SOUZA, E. R. (Org.). Avaliação por triangulação de métodos: abordagem de programas sociais. Rio de Janeiro: FIOCRUZ, 2005. 244 p.

NONATO J. R. Epistemologia e teoria do conhecimento em secretariado executivo: a fundação das ciências da assessoria. Fortaleza: Expressão Gráfica, 2009.

OLIVEIRA, S. A. de. Brevíssimo tratado conceitual da assessoria: para entender o secretariado. Guarapuava: Ideal, 2011.

Comun. \& Inf., v. 15, n. 2, p. 14-33, jul./dez. 2012 
PINHEIRO, J. R. Ética e comunicação: competências fundamentais para a secretária executiva das multinacionais. Secretariado Executivo em Revist@, v. 1, 2005. Disponível em:

<http://www.upf.br/seer/index.php/ser/article/view/1735/1145 >. Acesso em: 08 abr. 2012.

POLITO, R. Como falar corretamente e sem inibições. 64. ed. São Paulo: Saraiva, 1999.

PORTELA, K. C. A. Ferramentas do secretário executivo. Santa Cruz do Rio Pardo, SP: Viena, 2006.

REGO, F. G.T. do. Comunicação empresarial, comunicação institucional: conceitos, estratégias, sistemas, estrutura, planejamento e técnicas. 5. ed. v. 11. São Paulo: Summus, 1986.

RICHARDSON, R. J. (Org.). Pesquisa Social: métodos e técnicas. São Paulo: Atlas, 1999.

SABINO, R. F. ROCHA, F. G. Secretariado: do escriba ao webwriter. Rio de Janeiro: Braspot, 2004.

SILVA, R. J. Como falar muito bem. [S.1.]: Ed. Europa, 2007. Disponível em:

<http://dl.dropbox.com/u/6269563/apostilaoratoria.pdf>. Acesso em: 06 mar. 2012.

TAVARES, M. Comunicação empresarial e planos de comunicação: integrando teoria e prática. São Paulo: Atlas, 2007.

Comun. \& Inf., v. 15, n. 2, p. 14-33, jul./dez. 2012 